\title{
The Dermoscopic Patterns and Evolution of Acquired Melanocytic Nevi in Pediatric Age Group
}

\section{Pediatrik Yaş Grubunda Kazanılmış Melanositik Nevusların Dermoskopik Yapıları ve Gelişimleri}

\author{
Ilkay Ozer ${ }^{1}$, Murat Orhan Oztas $^{2}$, Esra Adisen $^{2}$, Mehmet Ali Gurer ${ }^{(\mathbb{D}}$
}

${ }^{1}$ Necmettin Erbakan University, Meram Faculty of Medicine, Department of Dermatology, Konya, Turkey

${ }^{2}$ Gazi University, Faculty of Medicine, Department of Dermatology, Ankara, Turkey ${ }^{3}$ Professor of Gazi University, Faculty of Medicine, Department of Dermatology, Ankara, Turkey

Address correspondence to: llkay Ozer, Necmettin Erbakan University Meram Faculty of Medicine Department of Dermatology, Konya, Turkey

e-mail: ilkay_8@yahoo.com

Geliş Tarihi/Received: 11 March 2021 Kabul Tarihi/Accepted: 14 April 2021

\begin{abstract}
Öz
Amaç: Pediatrik yaş dönemi nevogenez için dinamik bir yapıya sahip olup nevus gelişimi için önemli ip uçlarını bünyesinde barındırmaktadır. Bu çalışmada pediatrik yaş grubunda kazanılmış melanositik nevuslerin dermoskopik patern ve pigment ağ yapıları incelenerek banal ve atipik yapılı nevusların tanınmasına katkı sağlanması amaçlanmıştır.

Hastalar ve Yöntem: Çalışmamız haziran 2011- 2013 tarihleri arasında yapılmış prospektif bir çalışmadır. Çalışmaya nevogenez için yatkınlığı bulunmayan 150 pediatrik gönüllü dahil edilmiştir. Çocuklar 7 yaş ve altı ve 8 yaş ve üstü olarak iki gruba ayrılmıştır. Muayene edilen nevuslerden gövde ve ekstremite yerleşimli nevuslerin sayı, boyut, patern ve pigment yapıları incelenmiştir.

Bulgular: Nevus sayı ortalaması büyük yaş grubunda $(9,72)$ küçük yaş grubundan $(3,44)$ daha fazla olduğu izlendi. Her iki grupta da predominant patern yapısının globuler patern olduğu, 8 yaş ve üstü grubunda retiküler paterne sahip nevusların 7 yaş ve altı grubundan daha fazla olduğu izlendi $(p=0,03)$. Her iki grupta da globuler paterne sahip nevusların gövdede, retiküler paterne sahip nevusların ekstremite de daha yoğun olduğu izlendi $(p=0,001)$. Nevuslerin pigment ağ yapıları incelendiğinde en sık izlenen pigment ağ yapısı uniform olmakla birlikte 8 yaş ve üstü grupta santral pigmentasyon değişikliği bulunan nevusların daha fazla izlendiği görüldü $(p=0,001)$.

Sonuç: Pediatrik yaş grubunda kazanılmış melanositik nevusler sıklıkla globüler patern ve uniform pigment ağ yapısına sahip olsa da artan yaş ile birlikte retiküler paterne ve santral pigmentasyon değişikliğine sahip nevus sayısı artmaktadır.

Anahtar Kelimeler: Atipik nevus, dermoskopi, gelişim, nevus, patern yapısı, pigment ağ

\section{Abstract}

Aim: Pediatric age period has a dynamic structure for nevogenesis. In this paper, it was aimed to contribute to recognition of banal and atypical nevi through examining dermoscopic pattern and pigment network structures of acquired melanocytic nevi in pediatric age group.

Patients and Methods: Our study was a prospective conducted between june 2011 and june 2013. One hundred and fifty pediatric volunteers who were not predisposed to nevogenesis were included in the study. Children were divided into two groups as 7 and under, and 8 and over.

Results: It was observed that the mean number of nevus was higher in the older age group (9.72) than in the younger age group (3.44). It was observed that the predominant pattern structure was globular pattern in both groups, and nevi with reticular patter in the age group of 8 and above were more than the age group 7 and below $(p=0.03)$. In both groups, nevi with globular pattern were found to be denser in the trunk and nevi with reticular patter in the extremities $(p=0.001)$. When the pigment network structures of nevi were examined, it was observed that the most frequently observed pigment network was uniform, but nevi with central pigmentation changes were observed more frequently in the age group of 8 years and older $(p=0.001)$.

Conclusion: Although acquired melanocytic nevi in the pediatric age group often have a globular pattern and uniform pigment network, the number of nevi with reticular pattern and central pigmentation changes increases with increasing age.
\end{abstract}

Key words: Atypical nevus, Dermoscopy, Evolution, Nevus, Pattern structure, Pigment network
Cite this article as: Ozer I, Oztas MO, Adisen E, Gurer MA. The Dermoscopic Patterns and Evolution of Acquired Melanocytic Nevi In Pediatric Age Group. Selcuk Med J 2021;37(2): 96-100

"This article is licensed under a Creative Commons Attribution-NonCommercial 4.0 International License (CC BY-NC 4.0)"
Disclosure: None of the authors has a financial interest in any of the products, devices, or drugs mentioned in this article. The research was not sponsored by an outside organization. All authors have agreed to allow full access to the primary data and to allow the journal to review the data if requested. 


\section{INTRODUCTION}

Acquired melanocytic nevi are neoplasms that begin to form after birth, and the presence of irregular morphology is known to pose a risk for melanoma development (1). Primary cutaneous malignant melanoma arising from melanocytic cells of the skin accounts for $3 \%$ of all skin cancers and $75 \%$ of skin cancer-related deaths (2). With the introduction of dermoscopy, which provides a more detailed examination as compared to the examination with the naked eye, the diagnosis of malignant melanoma has been facilitated and the early clinical diagnosis rates have increased (3). Although dermoscopy is a key technique in the evaluation of melanocytic lesions, individual differences such as the age of the patient, skin phototype, and dominant nevus pattern are important for the decision about the melanocytic lesion (4). Six dermoscopic morphologies (reticular homogenous, reticular, globular-homogeneous, globular-reticular, globular, homogeneous) and six pigment networks (uniform, central hyperpigmentation, central hypopigmentation, peripheral hyperpigmentation, peripheral hypopigmentation, multifocal hyperpigmentation) have been defined for acquired melanocytic nevus dermoscopic sub-structure (5).

Studies have shown that childhood and adolescence are dynamic periods for the emergence of nevi and changes in their structures $(6,7)$. In this study, it was aimed to contribute to the recognition of banal and atypical nevi by examining the pattern and pigment network structures of melanocytic nevi in different body localizations in the pediatric age group.

\section{PATIENTS AND METHODS}

Our study was a prospective conducted between june 2011 and june 2013. One hundred and fifty volunteers aged between 1 and 18, who were admitted to dermatology outpatient clinic due to nonnevus complaints and their healthy relatives, who had acquired melanocytic nevi were included in the study after ethics committee approval (2011/52) had been obtained. The volunteers were divided to two groups according to the basal age of adolescence, 8 , as the ones 7 years and below, and the ones 8 years and above (8). The patients who had genetic or systemic disorders that could precipitate nevus development were excluded.

Nevi were examined using a digital dermoscope (Molemax III, derma instruments, Vienna, Austria), which can provide $30 x$ magnification. At the end of the study, the patterns of nevi located on the trunk, upper and lower extremities (excluding the palm of the foot) (globular, reticular, globular-reticular, homogeneous, reticular-homogeneous, globular-homogeneous formation) and pigment networks (uniform, central hyperpigmentation, central hypopigmentation, peripheral hyperpigmentation, peripheral hyperpigmentation, peripheral hypopigmentation) were evaluated and recorded. Since the nevi in the head and neck region and the palms and soles have a distinct pattern specific to their localization, they were not included in the pattern and pigment network examination.

\section{Statistical Analysis}

SPSS 15 program was used for data assessment. Descriptive data were expressed as number, percent for categorical variables, and continuous variables were presented with mean \pm standard deviation and median (max-min). In the comparison of continuous data, Mann Whitney U Test, Kruskal Wallis Variance Analysis and Wilcoxon Signed Ranks Test were used because the data did not conform to normal distribution. Chi-square significance test was used in comparison of categorical variables, and a value of $p$ $<0.05$ was considered statistically significant.

\section{RESULTS}

One hundred and fifty children under the age of 18 were included in our study. Children were divided into two groups as the ones aged 7 and below, and

Table 1. Demographic characteristics of the volunteers

\begin{tabular}{llll}
\hline & Group 7 & Group 8 & \\
\hline Age & & & \\
Mean \pm SD & $4.59 \pm 1.6$ & $12.13 \pm 2.58$ & \\
Median(Min; max) & $5.00(2 ; 7)$ & $12.00(8 ; 18)$ & \\
Gender & $39(52 \%)$ & $50(66.7 \%)$ & \\
Female & $36(48 \%)$ & $25(33.3 \%)$ & $\mathrm{P}=0.24$ \\
Male & & & \\
Skin phenotype & $47(62.7 \%)$ & $28(37.3 \%)$ & $\mathrm{P}=0.41$ \\
Phenotype II & $45(60 \%)$ & $30(40 \%)$ & \\
Phenotype III & & & \\
\hline
\end{tabular}


age 8 and above. There was no difference between the skin phenotype and gender distribution of the volunteers in the groups, and the epidemiological data and the number of nevi are shown in Table 1. In the dermatological examination, a total of 987 nevi were detected in the head, neck and extremities, palm soles, including the trunk. While the average number of nevi in the age group of 7 and below was 3.44 , the average number of nevi in the age group 8 and over was 9.72 , and it was found that the number of nevi increased with increasing age $(p<0.001)$.

A total of 845 nevi located on the trunk and extremities (185 nevi in the age group 7 and below, 660 in the age group 8 and over) were examined to determine pattern and pigment network structures. The distribution and sizes of nevi of the volunteers are given in Table 2. It was observed that the predominant pattern structure was globular in both groups, and nevi with reticular pattern were higher in the 8 and above group than in the 7 and below age group ( $p$ $=0.03$ ) (Table 3). In both groups, nevi with globular pattern were found to be denser on the trunk and nevi with reticular patter on the extremities $(p=0.001)$. When the pigment network structures of the nevi were examined, it was observed that the most frequently observed pigment network was uniform, but nevi with central pigmentation changes were observed more in the age group of 8 years and older $(p=0.001)$ (Table 4).

\section{DISCUSSION}

Our study was conducted with children under the age of 18, and the preadolescent and adolescent periods, in which nevus development and differentiation are observed intensely, are evaluated separately and the pattern and pigment structures of nevi in different anatomical locations are examined.

In our study, while the mean number of nevi was 3.44 in the younger age group, it was 9.72 in the older age group. It was observed that nevi were mostly located in the trunk and the number of nevi was higher in the older age group than in the younger age group. In previous studies with children, it was reported that the number of nevi increased with age $(9-13)$. In the study of Öztaş et al. (9) conducted with children aged between 0 and16, they reported the mean number of nevi as 2.94 in children under the age of 6 and 9.88 in children over 7 years old. Aguilera et al. (11) reported the mean number of nevi as 17.5 in all children and 30 in children aged 12-15 in their study conducted with children aged 1-15 years. Valiukeviciene et al. (12) reported that the number of nevi increased in adolescence, Scope et al. (13) reported that at least one new nevus developed in approximately three quarters of the children in the 3-year follow-up of 11-year-old children. Studies indicating an increase in melanocytic nevi with growth hormone replacement and the presence of estrogen receptors in nevi in children with Turners' syndrome show that the nevus number and hormonal factors may be related (14-16). In a study conducted with children aged 8-10 years in Spain, it was reported that there were more nevi in the trunk localization than the extremities and this was attributed to the nevogenic effect of intermittent sun exposure (17). In our study, it was found that the average nevus size of the 7 and below age group was smaller than the 8 and over age group. Histological findings of atypia can be observed in the histopathological examination of nevi that show growth in elderly individuals, but histologically no findings of atypia are observed in samples obtained from excision of growing nevi in children and adolescents (18).

In our study, presence of nevi with globular pattern was dominant in both age groups. It was observed that nevi with reticular patter increased in the age group of 8 years and older. In addition, it was observed that the nevi in the trunk localization were often globular and the nevi located in the extremities had more reticular patter. Öztaş et al. (9) reported that the most common

Table 2. Location, number and size of the nevi

\begin{tabular}{|c|c|c|c|}
\hline & 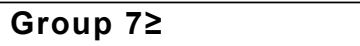 & Group $8 \leq$ & \\
\hline \multicolumn{4}{|l|}{ Location } \\
\hline Head and neck n(\%) & $71(27.5)$ & $67(9.2)$ & \\
\hline Trunk n(\%) & $88(34.1)$ & $314(43.1)$ & \\
\hline Upper extremity $n(\%)$ & $51(19.7)$ & $254(34.8)$ & \\
\hline Lower extremity $\mathrm{n}(\%)$ & $46(17.8)$ & $92(12.6)$ & \\
\hline Acral region $\mathrm{n}(\%)$ & $2(0.8)$ & $2(0.2)$ & \\
\hline Total nevus count/mean & $258 / 3.44$ & $729 / 9.72$ & $P<0.001$ \\
\hline \multirow[t]{2}{*}{ Nevus size } & $1.69 \pm 6.19$ & $4.20 \pm 9.13$ & \\
\hline & $(\min : 0.26-\max : 26.61)$ & $(\min : 0.11-\max : 53.58)$ & $P=0.001$ \\
\hline
\end{tabular}


Table 3. Pattern distribution according to age

\begin{tabular}{lll}
\hline & Group 7 & Group 8 \\
\hline Pattern structure & $\mathrm{n}(\%)$ & $\mathrm{n}(\%)$ \\
Globular & $81(43.8)$ & $245(18.9)$ \\
Globular-reticular & $34(18.4)$ & $125(31.7)$ \\
Reticular & $42(22.7)$ & $209(31.7)$ \\
Homogenous & $6(3.2)$ & $16(2.4)$ \\
Globular-homogenous & $21(11.4)$ & $38(5.8)$ \\
Reticular-homogenous & $1(0.5)$ & $27(4.1)$ \\
${ }^{*} \mathrm{P}=0.03$ chi-square & &
\end{tabular}

p:0.03 (chi-square) between age groups and dermoscopic pattern

globular pattern was observed in children aged 0-16 years, and that they did not detect a pattern difference with increasing age. In the study of Aguilera et al. (11) conducted with 180 children between the ages of 1 and 15 , it was found that the most common pattern was the lobular pattern and that adolescents had more nevi with reticular patter than young children. In the study of Scope et al. (18) conducted with 11-year-old children, they reported that the most common pattern was homogeneous pattern, followed by globular and reticular pattern, respectively. Changchien et al. (19) reported that under 12 years of age, the most common pattern is globular, and under 12 years of age, reticular pattern is observed more frequently, and reticular pattern nevus is more common in the extremities.

In the study of Piazza et al. (20) conducted with children aged 0-16 years, they reported that nevi with globuler pattern were frequently located in the trunk, and the reticular pattern nevi in extremities. In the study of Fonseca et al. (21) on adolescents with a mean age of 14 years, they reported that nevi with globular pattern in the trunk located nevi, and the reticular pattern in the extremity nevi were observed more frequently. For nevogenesis, Unna (1896) developed the Abtropfung hypothesis (melanocytic cell formed in the epidermis and descended into the dermis) and suggested that the nevus cells formed in the dermal-epidermal region initially started as junctional nevus, then progressed into the dermis and eventually became a compound nevus and finally the dermal nevus (22). On the other hand, unlike Unna's Abtropfung hypothesis, nevi with globular and reticular patterns have biologically different nevus subsets to age and anatomical localization $(13,21)$, the "structural or endogenous" pathway that starts in childhood is proposed to lead to nevi without globular or specific dermoscopic patterns, "acquired or exogenous "pathway is proposed to lead to nevi with reticular pattern and increased ultraviolet exposure due to advancing age is the most likely exogenous cause (23).

It has been suggested that nevi with globular pattern are late-term clinics of congenital nevi and that globular pattern is more frequent in the trunk due to the cephalo-caudal and axio-peripheral migration of melanoblasts $(19,24)$. Considering these hypotheses, the fact that nevi with reticular patterns were observed more frequently in the older age group and extremities in our study may be due to ultraviolet exposure.

In our study, it was observed that the predominate pigment network was uniform in both age groups, but the number of nevi with central pigment changes in the 8 and over age group was observed. In 7 and below age group, the difference in pigment network according to localization was not monitored, whereas

Table 4. Pigment network distribution according to age

\begin{tabular}{lll}
\hline & Group 7 & Group 8 $\leq$ \\
\hline Pigment network structure & $\mathrm{n}(\%)$ & $\mathrm{n}(\%)$ \\
Uniform & $175(94.6)$ & $517(78.3)$ \\
Central hyperpigmentation & $6(3.2)$ & $55(8.3)$ \\
Central hypopigmentation & - & $21(3.2)$ \\
Multifocal & $4(2.2)$ & $53(8)$ \\
Peripheral hyperpigmentation & - & $5(0.8)$ \\
Peripheral hypopigmentation & - & $9(1.4)$ \\
P=0.001 chi-square & &
\end{tabular}


in the 8 and over age group, it was observed that they had less central hyperpigmentation in the nevi in the trunk localization. The difference in age in the pigment network may indicate the effect of increased ultraviolet exposure to the nevus pigment network. Emiroğlu et al. (25) reported that the most common pigment network was central hyperpigmentation in their study conducted with the subjects with a mean age of 45 years. Zalaudek et al. (26) reported that uniform pigment network was observed the most in the $0-15$ age group, and that the number of nevi with central hyperpigmentation increased in the 16-30 age group and this change was attributed to an increased exposure to cumulative ultraviolet.

In conclusion, although acquired melanocytic nevi in the pediatric age group often have a globular pattern and uniform pigment network, the number of nevi with reticular pattern and central pigmentation changes increase with increasing age. The most likely culprit of this increase seems to be increased ultraviolet exposure.

Conflict of interest: Authors declare that there is no conflict of interest between the authors of the article.

Financial conflict of interest: Authors declare that they did not receive any financial support in this study.

Address correspondence to: Ilkay Ozer, Necmettin Erbakan University Meram Faculty of Medicine Department of Dermatology, Konya, Turkey

Tel: +905052584264 e-mail: ilkay_8@yahoo.com

\section{REFERENCES}

1. Hauschild A, Egberts F, Garbe C, et al. Melanocytic nevi. J Dtsch Dermatol Ges 2011;9:723-34.

2. Narayanan DL, Saladi RN, Fox JL. Ultraviolet radiation and skin cancer. Int J Dermatol 2010;49:978-86.

3. Gewirtzman AJ, Braun RP. Computerized digital dermoscopy. J Cosmet Dermatol 2003;2:14-20.

4. Zalaudek I, Schmid K, Marghoob AA, et al. Frequency of dermoscopic nevus subtypes by age and body site: A crosssectional study. Arch Dermatol 2011;147:663-70.

5. Hofmann-Wellenhof R, Blum A, Wolf $\mathrm{IH}$, et al. Dermoscopic classification of atypical melanocytic nevi (acquired melanocytic nevi). Arch Dermatol 2000;12:1575-80.

6. Haliasos EC, Kerner M, Jaimes N, et al. Dermoscopy for the pediatric dermatologist part III: Dermoscopy of melanocytic lesions. Pediatr Dermatol 2013;30:281-93.

7. Cohen $B$. To biopsy or not to biopsy changing moles in children and adolescents: Are we removing too many pigmented nevi in this age group? Comment on "Variables predicting change in benign melanocytic nevi undergoing short-term dermoscopic imaging" Arch Dermatol 2011;147:659-60.

8. Gönç EN. Normal puberte gelişimi ve puberte prekoks. Hacettepe Tıp Dergisi 2009;40:164-8.
9. Oztas $\mathrm{P}$, Ilhan MN, Polat $\mathrm{M}$, et al. Clinical and dermoscopic characteristics of melanocytic nevi in Turkish children and their relationship with environmental and constitutional factors. Dermatol Surg 2007;33:607-13.

10. Dogan G. Melanocytic nevi in 2783 children and adolescents in Turkey. Pediatr Dermatol 2007;24:489-94.

11. Aguilera P, Puig S, Guilabert A, et al. Prevalence study of nevi in children from Barcelona dermoscopy, constitutional and environmental factors. Dermatology 2009;218:203-14.

12. Valiukevicine $S$, Miseviciene I, Gollnick H. The prevalance of common acquired melanocyctic nevi and the relationship with skin type characteristics and sun exposure among children in Lithuania. Arch Dermatol 2005;141;579-86.

13. Scope A, Dusza SW, Marghoob AA, et al. Clinical and dermoscopic stability and volatility of melanocytic nevi in a population-based cohort of children in Framingham school system. J Invest Dermatol 2011; 131: 1615-21.

14. Bourguignon JP, Piérard GE, Ernould C, et al. Effects of human growth hormone therapy on melanocytic naevi. Lancet 1993;341:1505-6.

15. Ohata $\mathrm{C}$, Tadokoro $\mathrm{T}$, Itami $\mathrm{S}$. Expression of estrogen receptor $\beta$ in normal skin, melanocytic nevi and malignant melanomas. Journal of Dermatology 2008;35:215-21.

16. Mahé $E$, Beauchet $A$, de Paula Corrêa $M$, et al. Outdoor sports and risk of ultraviolet radiation-related skin lesions in children: Evaluation of risks and prevention. $\mathrm{Br} \mathrm{J}$ Dermatol 2011;165:360-7.

17. Karram S, Novy M, Saroufim M, et al. Predictors of BRAF mutation in melanocytic nevi: Analysis across regions with different UV radiation exposure. Am J Dermatopathol 2013; 35:412-18.

18. Scope A, Marghoob AA, Dusza SW, et al. Dermoscopic patterns of naevi in fifth grade children of the Framingham school system. Br J Dermatol 2008;158:1041-9.

19. Changchien L, Dusza SW, Agero AL, et al. Age and sitespesific varition in the dermoscopic patterns of congenital melanocytic nevi an aid to accurate classification and assessment of melanocytic nevi. Arch Dermatol 2008;144:1440-4.

20. Piazza CD, Yamada S, Marcassi AP, et al. Dermoscopic patterns of melanocytic nevi in children and adolescents: A cross-sectional study. An Bras Dermatol 2017;92:340-4.

21. Fonseca M, Marchetti MA, Chung E, et al. Cross-sectional analysis of the dermoscopic patterns and structures of melanocytic naevi on the back and legs of adolescents. $\mathrm{Br} \mathrm{J}$ Dermatol 2015;173:1486-93.

22. Krengel S. Nevogenesis--new thoughts regarding a classical problem. Am J Dermatopathol 2005;27:456-65.

23. Zalaudek I, Schmid K, Marghoob AA, et al. Frequency of dermoscopic nevus subtypes by age and body site: A crosssectional study. Arch Dermatol 2011;147:663-70.

24. Seidenari S, Pellacani G, Martella A, et al. Instrument, age and sitedependent variations of dermoscopic patterns of congenital melanocytic naevi: A multicentre study. $\mathrm{Br} J$ Dermatol 2006;155:56-61.

25. Emiroglu N, Sallahoglu K, Cengiz FP, et al. Three years dermoscopic follow-up of atypical nevi. Dermatol Ther 2020;33:e13205.

26. Zalaudek I, Grinschgl S, Argenziano G, et al. Age related prevalence of dermoscopy patterns in acquired melanocytic naevi. Br J Dermatol 2006;154:299-304. 